Матеріали науково-практично конференці з участю міжнародних спеціалістів «Актуальні питання діагностики, лікування, раціонально фармакотерапі , диспансеризаці та реабілітаці в практиці сімейного лікаря»

УДК 615.33.036.8:616.24-002

\title{
АНАЛІЗ СХЕМ ФАРМАКОТЕРАПІ НЕГОСПІТАЛЬНО ПНЕВМОНІ В УМОВАХ СТАЦІОНАРУ
}

○О. Є. Самогальська, О. В. Бондар

ДВНЗ «Тернопільський державний медичний університетімені I. Я. Горбачевського МОЗ України»

Пневмонія залишається важливою і медичною, і соціальною проблемою, що пов'язано з суттєвими економічними втратами внаслідок цього захворювання. Загальні витрати на лікування пневмоні в світі становить понад 10 млрд дол.

Метою роботи було провести клініко-фармацевтичний аналіз схем лікування позагоспітально пневмоні в умовах стаціонару.

Проаналізовано 65 карт стаціонарних хворих віком від 16 до 87 років.

Розподіл хворих відповідно до сучасно класиФікаці пневмоні був такий: 1-ша клінічна група (КГ) - 0 (0 \%) хворих, 2-га КГ - 21 (32,3 \%) хворих, 3-тя КГ - 44 (67,7\%) хворих. Хворим 2 КГ були призначені як монотерапія перорально: аугментин, амоксицилін або макроліди (макропен, сумамед) (46,2 \% хворих). Монотерапія цефтріаксоном в/м була призначена 1 хвориму (1,5\%). Серед хворих 3- групи було застосовано комбіновану антибіотикотерапію (АБТ), а саме, у 24 (54,5\%) - аугментин та макроліди (70\%), захищені пеніциліни поєднували 3 респіраторними фторхінолонами у 6,8 \% випадків, макроліди і респіраторні фторхінолони у 14,6 \% випадків, інші - у 8,6 \% випадків. Курс АБТ складав у хворих 2- КГ 5-7 днів, у хворих 3- КГ 10-14 днів. Проведено розрахунки методами фармакоекономічного аналізу вартості різних схем терапі. Вартість фармакотерапі хворих 1 групи коливалась від 1583 до 1749 грн, 2 групи - від 1630 до 2157 грн.

Для раціонального вибору схеми лікування негоспітально пневмоні можна скористатися даними, отриманими за допомогою фармакоекономічного аналізу проаналізованих схем фармакотерапі . 